\title{
Elazığ İlinde Yetişen Morus nigra L. Ekstraktlarının Antioksidan ve Antimikrobiyal Aktivitelerinin ve Antibiyotiklerle Sinerjistik Etkisinin Belirlenmesi
}

\author{
Determination of Antioxidant and Antimicrobial Activities and Synergistic effect with \\ Antibiotics of Morus nigra L. Extracts Grown in Elazig Province
}

\author{
Osman AKMEŞE ${ }^{1, a}$, Tuba ACET*2,b, Kadriye ÖZCAN ${ }^{3, c}$ \\ ${ }^{1}$ Gümüşhane Üniversitesi, Fen Bilimleri Enstitüsü, Biyoteknoloji Ana Bilim Dall, 29100, Gümüşhane \\ ${ }^{2}$ Gümüşhane Üniversitesi, Mühendislik ve Doğa Bilimleri Fakültesi, Genetik ve Biyomühendislik Bölümü,29100, Gümüşhane \\ ${ }^{3}$ Giresun Üniversitesi, Mühendislik Fakültesi, Genetik ve Biyomühendislik Bölümü, 28200, Giresun
}

• Geliş tarihi / Received: 27.04.2020 • Düzeltilerek geliş tarihi / Received in revised form: 27.08.2020 • Kabul tarihi / Accepted: 31.08 .2020

\begin{abstract}
$\ddot{O} z$
Antimikrobiyal ajan olarak kullanılan ilaçların olası yan etkileri ve mikroorganizmaların bu ilaçlara karşı direnç kazanması, insan sağlığı için büyük tehlike oluşturmaktadır. Bu durum bilim çevrelerini yeni arayışlara itmiştir. Gıda olarak tüketilen pek çok bitkisel ürünün aynı zamanda hastalıklardan korunma amacıyla da halk tarafından kullanıldığı bilinmektedir. Ancak, bunlardan pek çoğu halen bilimsel verilerle doğrulanmamıştır. Bu bakımdan, mevcut çalışmada Elazığ ilinden toplanan ve yöre halkı tarafindan geleneksel olarak pek çok rahatsızlığın hafifletilmesinde kullanılan Morus nigra L. (karadut) taze meyve ekstraktlarının (etanol, metanol ve etil asetat) pomolojik özellikleri, toplam fenolik ve toplam flavonoid içerik değerleri ile toplam antioksidan kapasiteleri belirlendi. Bununla birlikte, etanol ekstraktının fitokimyasal içeriği RP-HPLC ile değerlendirildi. Ayrıca bunların, antimikrobiyal özellikleri ve antibiyotiklerle (kloramfenikol, novobiosin ve nalidiksik asit) olan sinerjileri test edildi. Etanol ekstraktının toplam fenolik içerik değeri ve antioksidan özellikleri diğerlerine göre anlamlı derecede yüksek bulundu. Bu ekstraktın major bileşeni ise klorojenik asit olarak tespit edildi. Ekstraktların test mikroorganizmalarına karşı düşük etkinlik gösterdiği, bununla beraber metanol ekstraktı/kloramfenikol kombinasiyonu haricinde tüm ekstrakt antibiyotik karışımlarının ciddi bir patojen olan $P$. aeroginosa üzerine tam sinerjik etki gösterdiği tespit edildi. Tam sinerji olması ise, antibiyotiğin daha düşük dozda daha etkili olmasını sağlaması açısından oldukça önemlidir. Sonuç olarak, M. nigra meyve ekstraktlarının sahip olduğu biyolojik aktiviteleri nedeniyle, gıda ve ilaç endüstrilerinde doğal ve alternatif bir kaynak olarak kullanılma potansiyeline sahip olduğu düşünülmektedir.
\end{abstract}

Anahtar kelimeler: Antimikrobiyal, Antioksidan, HPLC, Morus nigra L., Sinerjik Etki

\begin{abstract}
Possible side effects of drugs used as antimicrobial agents and microorganisms' resistance to these drugs pose a great danger to human health. This situation led to the scientific community to new searches. It is known that many herbal products consumed as food are also used by the public for the protection of diseases. However, many of these are still not confirmed by scientific data. In this regard, in the current study, Morus nigra L. (black mulberry) fresh fruit extracts (ethanol, methanol and ethyl acetate) collected from Elazığ province and used by local people to alleviate many diseases, total antioxidant content of total phenolic and total flavonoids capacities were determined. However, the phytochemical content of the ethanol extract was evaluated by RP-HPLC. In addition, their antimicrobial properties and synergies with antibiotics (chloramphenicol, novobiosin and nalidixic acid) were tested. The total phenolic content value and antioxidant properties of ethanol extract were significantly higher than the others. The major component of this extract was determined as chlorogenic acid. It was determined that the extracts showed low efficacy against the test microorganisms, however, all extract antibiotic mixtures exhibited a full synergistic effect on P. aeroginosa, a serious pathogen, except for the methanol extract / chloramphenicol combination. The full synergy is important in terms of ensuring that the antibiotic is more effective at a lower dose. As a result, due to the biological activities of M. nigra fruit extracts, it is thought to have the potential to be used as a natural and alternative source in the food and pharmaceutical industries.
\end{abstract}

Keywords: Antimicrobial, Antioxidant, HPLC, Morus nigra L., Synergistic Effect

\footnotetext{
*b Tuba ACET; tubaacet@ hotmail.com, Tel: (0456) 2331000 (dâhili:1881), orcid.org/0000-0002-0981-9413

${ }^{\mathrm{a}}$ orcid.org/0000-0001-9300-8324 ${ }^{\mathrm{c}}$ orcid.org/0000-0002-4913-6035
} 


\section{Giriş}

Genellikle dut olarak adlandırılan Morus cinsi, 16 'dan fazla tür içerir ve Moraceae familyasına mensuptur (Ercişli ve Orhan, 2007). Dut ağaçları dünya genelinde tropikal, subtropikal ve 1 limlı olmak üzere farklı iklimsel koşullarda yaşayabilirler ve deniz seviyesinden itibaren 4000 metreyi aşan yüksekliklere kadar geniş bir yayılış göstermektedirler (Vijayan vd., 2011). Bunlardan özellikle Morus nigra L. (karadut), sahip olduğu zengin antioksidan içerik ve lezzetinten dolayı hem gida olarak hem de pek çok rahatsızlı̆̆n hafifletilmesi amaciyla insanlar tarafindan sıklıkla tüketilmektedir (Kostic vd., 2013). Örneğin, karadutun çeşitli kısımları (meyve, kök ve kabuk gibi) boğaz ağrısı, anemi, demir eksikliği, bademcik iltihabı, yara iyileştirme, hipertansiyon, diyabet ve artrit tedavisinde; ateş düşürücü ve diüretik olarak karaciğeri koruma amaçlı, görme güçlügünü tedavi edici, kan basıncını azaltma ve kardiyovasküler hastalikların önlenmesinde geleneksel tıpta kullanılmaktadır (Jiang, 2011). Bu bitkinin önemli miktarlarda biyoaktif maddeler barındırdığı ve antimikrobiyal, antienflamatuar, antioksidatif, antidiyabetik, antiaterojenik, antiaging, antiobezite ve nöroprotektif gibi farkl1 pek çok biyolojik aktiviteler sergilediği bilimsel çalışmalarla da ortaya konmuştur (Hojjatpanah vd., 2011; Diab vd., 2020). Sergilemiş olduğu çeşitli farmakolojik aktiviteleri, gıda katk1 maddesi olarak güvenli kullanımı ve buna bağlı olarak ulusal ekonomide yüksek değere sahip oluşu ile, Morus cinsi bitkiler son yıllarda giderek daha fazla dikkat çekmektedir (Yan vd., 2020).

Küresel iklim değişikliği ve yaşam biçimlerinin değişmesiyle pek çok problem ortaya çıkmıştır. Bunların başında da dünya genelinde halk sağlığını ciddi biçimde tehdit eden, antibiyotik dirençli organizmaların neden olduğu enfeksiyonlar gelmektedir (Özcan ve Acet, 2018). $\mathrm{Bu}$ problemin çözümünde de ne yazık ki mevcut antibiyotikler yetersiz kalmaktadır ve bu durum acil olarak çözülmesi gereken bir hal almıştır. Bilim insanları yeni antibiyotikler keşfetme veya doz artırımı gibi birtakım çabalar içinde olsalar da, bunlar patojen suşlar üzerinde ya yetersiz kalmakta ya da insanlar üzerinde ciddi yan etkilere neden olmaktadırlar (Rehman vd., 2020). $\mathrm{Bu}$ bakımdan, bilinen antibiyotiklerin doğal bileşenlerle zenginleştirilerek etkinliğinin artırılması yaklaşımı doğmuştur (Wang vd., 2020). Özellikle bitki ekstraktları ile antibiyotiklerin sinerjistik etkilerinin bilinmesi, doğal, ucuz ve daha az yan etkiye sahip alternatif bir yaklaşım olarak ortaya çıkmaktadır. Böylelikle daha düşük dozda antibiyotik kullanılarak daha etkili sonuçlar elde etmek mümkün olabilmektedir. Morus nigra'nın başta antioksidan ve antimikrobiyal özellikler olmak üzere, pek çok biyolojik aktiviteler sergilediği bilinmektedir (Budiman vd., 2020; Thakur vd., 2020). Ancak, literatürde Elazı ğ ilinden toplanan karadut ile yapılan benzer bir çalışmaya rastlanmamıştır. $\mathrm{Bu}$ bölgenin özelliği farklı iklim ve yükseltiye sahip olmasıdır. Bitkilerin bu zorlu koşullarda hayatta kalabilmek için, onların biyolojik aktivitelerinden sorumlu olan, sekonder metabolit kompozisyonlarını değiştirdiği bilinmektedir (Alhaithloul vd., 2020). Bu yüzden mevcut çalışmamızda, Elazığ ilinin yüksek kesimlerinden toplanan ve yerel halk tarafindan geleneksel olarak tedavi amaçlı kullanılan, Morus nigra $L$. (karadut) taze meyvelerinin: $i$-) pomolojik, $\left.i i^{-}\right)$ toplam fenolik, toplam flavonoid içerik değerleri ve antioksidan, iii-) antimikrobiyal ve $i v$-) antibiyotiklerle sergilediği sinerjik aktivitelerinin belirlenmesi ve $v$-) fenolik bileşenlerinin analiz edilmesi amaçlanmıştır.

\section{Materyal ve Metot}

\section{1. Örneklerin Toplanmast}

Morus nigra L. meyve örnekleri 2018 tarihinin Temmuz ayında Elazığ ilinden toplandı (lokasyonu $38.77082^{\circ}$ kuzey-38.91900 güney ve rakımı ise $1242 \mathrm{~m}$ olarak belirlendi). Örnekler toplanırken meyvelerin ezilmemesi amaciyla porsiyonlara ayrıld 1 ve hava geçirmeyen kilitli poşetlere konarak sonraki analizler için $-20{ }^{\circ} \mathrm{C}$ 'de muhafaza edildi.

\section{2. Örneklerin Pomolojik Özellikleri}

Meyve örnekleri toplanırken pomolojik özelliklerinin belirlenmesi amaciyla rastgele seçilen 10 adet meyvenin boy ve en ölçümleri $0.05 \mathrm{~mm}$ hassasiyete sahip kumpas ile yapıld 1 ve daha sonra hassas terazide (Kern, ABJ-NM/ABS$\mathrm{N}$, Balingen-Almanya) meyvelerin ağırlıkları ölçüldü. Meyvelerin nem oranının belirlenmesi amaciyla örnekler $40{ }^{\circ} \mathrm{C}$ 'ye ayarlanmış etüve (Daihan Scientific, ThermoStable IG-105, Güney Kore) yerleştirilip belirlenen zaman aralıklarında ağırlık ölçümleri yapıldı ve ağırlığın değişmediği ardışık tartımla birlikte işlem sonlandırılarak kuru ağırlı hesaplaması yapıldı. Morus nigra L. meyve örneklerinin $\mathrm{pH}$ değerinin belirlenmesi maksadıyla meyve homojenize edilerek kaba filtre kâğıdından geçirildi. Elde edilen meyve suyunun pH's1 pH metre cihazi (Metler Toledo, SevenCompact S210, ABD) ile ölçüldü. Son 
olarak örneklerin renk ölçümleri renk ölçer cihazı ile ölçüldü.

\section{3. Örneklerin Ekstraksiyonu}

Meyve örneklerinin ekstraksiyonu bazı modifikasyonlar uygulanarak Sánchez-Salcedo vd., (2015)'e göre yapıldı. Ekstraksiyon çözeltisi olarak etanol, metanol ve etil asetat çözeltileri kullanıldı. Ekstraksiyon için örnekler önce oda sıcaklığında homojenize edildi ve ardından $2.5 \mathrm{~g}$ örneklerin üzerine $10 \mathrm{ml}$ ekstraksiyon çözücüleri eklendi ve örnekler 1 saat boyunca $25{ }^{\circ} \mathrm{C}$ 'de ultrasonik su banyosunda (Wisd Laboratory Instruments, WUC-D10H, Almanya) sonikasyona tabi tutuldu. Daha sonra karışım, 5 dakika boyunca 2500 rpm'de santrifüjlendi (Beckman Coulter, Allegra X-30R Centrifuge, ABD) ve süpernatant kısım alındı. Pellet kısım üzerine $5 \mathrm{ml}$ çözücü ilave edildi ve iki ek ekstraksiyon daha yapıld1. Son ekstraksiyon öncesi ekstraksiyon çözeltisi eklenen pellet kısım bir gece boyunca +4 ${ }^{\circ} \mathrm{C}$ 'de soğutucuda bekletildi ve tekrar 1 saat süreyle sonike edilip ardından santrifüj işlemine tabii tutuldu. Toplanan üç süpernatant kısımın son hacmi $25 \mathrm{ml}$ olacak biçimde kendi çözücüleri ile tamamlandı. Ekstraktlar $0.45 \mu \mathrm{m}$ por çapına sahip şırınga ucu filtreden geçirildikten sonra $5 \mathrm{ml}$ hacimdeki porsiyonlara ayrıld1 ve sonraki analizler için $-20{ }^{\circ} \mathrm{C}$ 'de muhafaza edildi. Ekstraksiyon sonrasinda örnek ekstraktları; MN1 (etanol Morus nigra L. meyve ekstraktı), MN2 (metanol M.nigra L. meyve ekstraktı), MN3 (etil asetat $M$. nigra L. meyve ekstraktı) olmak üzere kodlandi.

\subsection{Toplam Fenolik İçeriğin Belirlenmesi}

Ekstraktların toplam fenolik madde analizi FolinCiocalteu yönteminde küçük uyarlamalarla 96 kuyucuklu plakalarda yapıldı (Beara vd., 2014). Dut ekstraktları kendi çözücüleri ile 10 kat seyreltildi. Ekstraksiyon ve standart çözeltilerinden $25 \mu 1$ alınarak üzerine $125 \mu 1,1 / 10$ yoğunluktaki Folin-Ciocalteu fenol reaktifi eklendi. 10 dakika beklendikten sonra karışıma $100 \mu 1 \mathrm{Na}_{2} \mathrm{CO}_{3}$ (\%7.5) çözeltisi eklendi ve oda sicaklığında karanlıkta 2 saat reaksiyonun tamamlanması beklendi, $760 \mathrm{~nm}$ dalga boyunda köre karş1 okundu. Sonuçlar gallik asit eşdeğeri/taze meyve (mgGAE/gTM) olarak hesapland1.

\subsection{Toplam Flavonoid İçeriğin Belirlenmesi}

Dut ekstraktlarının toplam flavonoid içeriğini belirlemek maksadıyla 96 kuyucuklu plakaya uyarlanan alüminyum klorür kolorimetrik yöntem kullanıldı (Beara vd., 2014). Ekstraktlardan ve gerekli seyreltmeler yapılan standart çözeltilerden $30 \mu \mathrm{l}$ alınarak üzerine sirasiyla $80 \mu \mathrm{l}$ metanol, $6 \mu 1$ $\% 10$ 'luk alüminyum klorür, $6 \quad \mu 1 \quad 1 \quad \mathrm{~mol} / 1$ potasyum asetat ve $125 \mu \mathrm{l}$ ultra saf su ilave edildi. Oda sicaklığında ve karanlıkta 30 dakika reaksiyonun gerçekleşmesi için beklendi. Mikroplaka okuyucuda, $415 \mathrm{~nm}$ dalga boyunda köre karşı okuma yapıldı. Sonuçlar kuersetin eşdeğeri/taze meyve (mg QE/g TM) olarak verildi.

\subsection{Antioksidan Aktivite Analizleri}

\subsubsection{DPPH Radikali Süpürme Yöntemi}

Dut ekstraktlarının, DPPH (2,2-difenil-1pikrilhidrazil) radikali süpürücü etkisi, SolerRivas vd., (2000)'nin 96-kuyucuklu mikroplakalar için metoda göre yapıldı. Ekstraktlardan ve ve gerekli seyreltmeler yapılan standart çözeltilerden $10 \mu$ alınarak üzerine $100 \mu 1$ DPPH çözeltisi eklendi ve karışım metanol ile $190 \quad \mu$ l'ye tamamlandı. Oda sicaklığında karanlıkta 1 saat bekleme süresinden sonra $515 \mathrm{~nm}$ dalga boyunda mikroplaka okuyucuda köre karşı okundu. Sonuçlar hem standart eğri grafiği oluşturularak hem de $\mathrm{IC}_{50}$ yöntemiyle değerlendirildi. Standart ve pozitif kontrol olarak sentetik ve doğal antioksidan kimyasallar kullanıldı. Doğal antioksidan olarak askorbik asit, sentetik antioksidan olarak troloks tercih edildi. Sonuçlar hem eşdeğerlik hem de $\mathrm{IC}_{50}$ olarak verildi.

\subsubsection{ABTS Radikali Süpürme Yöntemi}

Dut ekstraktlarının ABTS giderme aktiviteleri, Silva vd., (2007)'e göre 96-kuyucuklu mikroplakalarda gerçekleştirildi. Ekstraktlardan ve gerekli seyreltmeler yapilan standart çözeltilerden $8 \mu \mathrm{l}$ alınarak, üzerine $230 \mu \mathrm{l}$ ABTS (saf su ile seyreltilerek $734 \mathrm{~nm}$ dalga boyunda 0.7 Abs olarak ayarland1) çözeltisi ilave edilerek reaksiyon başlatıld1. Karanlıkta, $30{ }^{\circ} \mathrm{C}$ 'de 6 dakika reaksiyonun bitmesi beklendi. Reaksiyonun bitişiyle birlikte örnekler ve standart çözeltiler 734 $\mathrm{nm}$ dalga boyuna ayarlanmış olan mikroplaka okuyucuda köre karşı okundu. Sonuçlar hem standart eğri grafiği oluşturularak hem de $\mathrm{IC}_{50}$ yöntemiyle değerlendirildi. Standart ve pozitif kontrol olarak sentetik ve doğal antioksidan kimyasallar kullanıldı. Doğal antioksidanları temsilen askorbik asit, sentetik antioksidanları temsilen troloks tercih edildi. Sonuçlar hem eşdeğerlik hem de $\mathrm{IC}_{50}$ olarak verildi. 


\subsubsection{Toplam Antioksidan Kapasite (Fosfomolibdat) Yöntemi}

Ekstraktların toplam antioksidan kapasitesi, fosfomolibdat test yönteminde küçük değişiklikler yapılarak 96 kuyucuklu mikroplakalarda spektrofotometrik olarak ölçüldü (Zengin vd., 2014). Bunun için önce, $300 \mu 1$ numune üzerine $300 \mu \mathrm{l}$ fosfomolibdik asit kompleksi ilave edildi. Reaksiyonun gerçekleşmesi için deney tüpleri daha önceden ayarlanan $95^{\circ} \mathrm{C}$ 'deki su banyosunda (Memmert, WNE 10, Almanya) 90 dakika bekletildi. Ardından, soğumuş karışım otomatik pipet yardımıyla 96 kuyucuklu plakaya $250 \mu 1$ hacimde enjekte edildi ve mikroplaka okuyucuda 695 nm'de köre karşı (distile su) okundu. Toplam antioksidan kapasite askorbik asit eşdeğeri (mg AAE/g ekstrakt) ve troloks eşdeğeri (mg TE/g TM) olarak hesaplandi.

\subsubsection{Yüksek Performanslı Stvi Kromotografisi (HPLC) Analizi ile Fenolik Madde İçeriğinin Belirlenmesi}

Toplam fenolik madde miktarı en yüksek olan etil asetat ekstraktının fenolik bileşen analizi Özcan vd., (2019)'a göre gerçekleştirildi. Analiz kapsamında, Shimadzu Marka HPLC cihazı ile dut bitkilerinde yaygin olarak görülen 23 adet fenolik bileşiğin varlığı araştırıldı. Gallik asit, protokatekuik asit, kateşin, p-hidroksi benzoik asit, klorojenik asit, kafeik asit, epikateşin, şiringik asit, vanilin, $p$-kumarik asit, ferulik asit, sinapinik asit, benzoik asit, $o$-kumarik asit, rutin, hesperidin, rosmarinik asit, eriodiktiol, sinnamik asit, kuersetin, luteolin, kaemferol ve apigenin fenolik bileşiklerinin miktarları $\mu \mathrm{g} / \mathrm{g}$ ekstrakt olarak verildi.

Analiz için pompa (LC-10 ADvp), degazör ünitesi (DGU-14A), otosampler (SIL-10 ADvp) ve detektör (DAD, $\chi \max =278$ ) içeren Shimadzu Marka HPLC sistemi ve Agilent Eclipse XDBC18 $(250 \times 4.60 \mathrm{~mm}, 5 \mu \mathrm{m}$ partikül büyüklüğü) kolonu, CTO-10Avp kolon firını kullanıldı. Mobil faz \%3'lük asetik asit çözeltisi (Mobil faz A) ve metanol (Mobil faz B), faz akış hızı $0.8 \mathrm{ml} / \mathrm{dk}$., akış tipi gradient elüsyonu ve enjeksiyon hacmi ise $20 \mu \mathrm{l}$ olarak belirlendi.

\subsection{Dut Ekstraktlarının Antimikrobiyal Özelliklerinin ve Antibiyotiklerle Olan Sinerjisinin Belirlenmesi}

\subsubsection{Disk Difüzyon Yöntemi}

Dut ekstraktlarının antimikrobiyal etkinlikleri disk difüzyon yöntemiyle belirlendi (CLSI, 2007). Gram pozitif bakteriler olarak Enterococcus faecalis ATCC 29212, Staphylococcus aureus ATCC 25923, Vankomisin dirençli Enterococcus faecium DSMZ 13590, Metisilin dirençli Staphylococcus aureus ATCC 43300, Bacillus cereus ATCC 9634, Listeria monocytogenes ATCC 7644; gram negatif bakteriler olarak Pseudomonas aeruginosa ATCC 27853, Yersinia enterocolitica ATCC 27729, Klebsiella pneumoniae ATCC 13883, Vibrio parahaemolyticus ATCC 17802, Escherichia coli O157:H7 ATCC 35150, Proteus vulgaris FMC 1 ve maya- küf olarak Candida tropicalis ATCC 13803, Aspergillus flavus ATCC 46283 test organizmaları olarak kullanıldı.

Test organizmalarının taze kültürleri hazırlandı ve 0.5 McFarland bulanıklığına $\left(1.5 \times 10^{8}\right.$ mikroorganizma/ml) seyreltildi. Daha sonra her bir mikroorganizmanın Müller-Hinton agar besiyeriye inokülasyonu gerçekleştirildi. Test mikroorganizması uygulanmış petrilerin üzerine $6 \mathrm{~mm}$ çapında steril boş disk yerleştirildi ve disklere $60 \mathrm{mg} / \mathrm{ml}$ konsantrasyondaki $20 \quad \mu l$ ekstrakt solüsyonu emdirildi. Petriler 2 saat $4^{\circ} \mathrm{C}$ 'de bekletilerek ekstraktlarının agara difüzyonu sağlandı. Pozitif kontrol olarak kloramfenikol, novobiosin, nalidiksik asit; negatif kontrol olarak DMSO kullanıldı. Bakteriler için $37{ }^{\circ} \mathrm{C}$ 'de 24 saat, mayalar için $28^{\circ} \mathrm{C}^{\prime}$ de 48 saat inkübasyon sonrasında disklerin çevresinde oluşan zon çapları dijital kumpasla ölçüldü.

\subsubsection{Dut Ekstraktlarının MiK ve MBK Değerlerinin Belirlenmesi}

Dut ekstraktlarının MiK (minimum inhibisyon konsantrasyonu) değerleri broth dilüsyon metodu kullanılarak 96-kuyucuklu mikroplakalar ile belirlendi (CLSI, 2007). Besiyeri olarak MüllerHinton Broth kullanıldı. Öncelikle tüm kuyucuklara $100 \mu 1$ sivı besiyeri dağıtıldı. Daha sonra ise dut ekstraktlarından $100 \mu \mathrm{l}$ alınarak ilk kuyucuğa eklendi ve seri dilüsyonla seyreltme işlemi gerçekleştirildii. Seri seyreltme ile 0.016$8.2 \mathrm{mg} / \mathrm{ml}$ aralığında 10 farklı konsantrasyon elde edildi. Aynı şekilde novobiosin, nalidiksik asit, kloroform ve kloramfenikol için seri seyreltmeyle $0.25-128 \mu \mathrm{g} / \mathrm{ml}$ aralığında 10 farklı konsantrasyon elde edildi. Son olarak, $10 \quad \mu 1$ mikroorganizmaların süspansiyonları $\quad(0.5$ MacFarland bulanıklığı) mikroplakalara inoküle edildi. Bakteriler için $37{ }^{\circ} \mathrm{C}$ 'de 24 saat boyunca, mayalar için $28{ }^{\circ} \mathrm{C}$ 'de 48 saat boyunca inkübasyondan sonra mikroorganizmaların 
üremesi kontrol edildi. Dut ekstraktları ve seçilen antibiyotiklerin, mikroorganizmaların çoğalmasını engelleyen en düşük konsantrasyonları MIC değerleri olarak belirlendi. Pozitif kontrol olarak kloramfenikol, novobiosin, nalidiksik asit; negatif kontrol olarak DMSO kullanıldı.

MBK (minimal bakterisidal konsantrasyon) değerlerinin belirlenmesi için ise her kuyudan 10 $\mu 1$ broth alındı, Müller-Hinton agara aşılandı ve 37 ${ }^{\circ} \mathrm{C}$ 'de 24 saat boyunca bakteriler için, $28{ }^{\circ} \mathrm{C}$ 'de 48 saat boyunca mayalar için inkübasyona bırakıldı. Dut ekstraktlarının bakterilerin \%99.9'unu öldürdüğü en düşük konsantrasyon MBC değeri olarak belirlendi.

\subsubsection{Dut Ekstraktarının Antibiyotiklerle Olan Sinerjisinin Belirlenmesi}

Checkboard yöntemi; dut ekstraktları ile seçilen antibiyotikler arasındaki sinerji checkboard yöntemi ile incelendi (Fadli vd., 2012). Ekstrakt ve antibiyotik kombinasyonlarının sinerjilerinin belirlenmesi amaciyla Vankomisin dirençli Enterococcus faecium DSMZ 13590, MRSA ATCC 43300 ve Pseudomonas aeruginosa ATCC 27853 test mikroorganizmaları olarak seçildi. Novobiosin, nalidiksik asit, kloramfenikol ve dut ekstraktlarının başlangıç konsantrasyonu 16xMIC olarak hazırlandi. Ekstrakt ve antibiyotik kombinasyonlarını oluşturmak için her seyreltik 1:1 oranında karıștırıldı ve elde edilen kombinasyon karışımları $100 \mu \mathrm{l}$ hacimde olacak şekilde ilk kuyucuklara pipetlendi. Seri iki kat seyreltme ile 4xMIC'den MIC/128'e kadar 10 farklı dilüsyon elde edildi. Daha sonra ise $10 \mu \mathrm{l}$ 0.5 MacFarland bulanıklığına ayarlanan mikroorganizmalar kuyucuklara inoküle edildi. Son olarak mikroplakalar $37{ }^{\circ} \mathrm{C}$ 'de 24 saat boyunca inkübe edildi. Mikroorganizmal büyümenin olmadığ1 en düşük konsantrasyon, kombinasyonların MIC değeri olarak belirlendi.

Kombinasyon analiz sonuçları aşağıdaki denklemden faydalanılarak, FICI (fraksiyon inhibitör konsantrasyon indeksi) değerleri hesaplanarak elde edildi (Didry vd., 1993).

$\mathrm{FICI}=(\mathrm{MICA} / \mathrm{B} / \mathrm{MICA})+(\mathrm{MICB} / \mathrm{A} / \mathrm{MICB})$

Bu eșitlikte;

MICA; sadece dut ekstraktlarının,

MICB; sadece antibiyotiklerin,

$\mathrm{MICA} / \mathrm{B}$; dut ekstraktlarının kombinasyon içindeki,

MICB/A; antibiyotiklerin kombinasyon içindeki MIC değerlerini temsil etmektedir.
FICI $\leq 0.5$ tam sinerji, $\quad 0.5<\mathrm{FICI} \leq 0.75$ kısmi sinerji, $\quad 0.76<\mathrm{FICI} \leq 1) \quad$ sinerjistik etkileşimin olmaması ve FICI $>2$ antagonistik etkilişim olarak yorumlandı (Kuok vd., 2017).

\section{8. İstatistiksel Analizler}

Yapılan analizler 3 tekrarlı olarak çalışıldı ve elde edilen sonuçlar IBM SPSS Statistics 21 programında, One-way ANOVA ile hesaplandı ve önemli farklılıklar Duncan'ın çoklu sıra testleri ile belirlenip $\mathrm{p}<0.05$ değerleri anlamlı olarak kabul edildi.

\section{Bulgular ve Tartışma}

\subsection{Morus nigra L. Meyve Örneklerine Ait Pomolojik Özellikler}

Rastgele seçilen meyvelerin boy-en, ağırlık ve renk ölçümleri yapılmıştır (Tablo 1-2). Elde edilen sonuçlara göre, örneklerinin ortalama ağırlığının (4.61 g), karadut üzerine yapılan benzer çalışmalara oranla, daha yüksek olduğu görülmüştür (Güneş ve Çekiç, 2004; Ercişli ve Orhan, 2007).

Tablo 1. Meyve örneklerinin boy-en ve ağırlık ölçümleri

\begin{tabular}{lc}
\hline & Ortalama \\
\hline Boy ölçümleri $(\mathrm{cm})$ & $2.51 \pm 0.18$ \\
En ölçümleri $(\mathrm{cm})$ & $1.69 \pm 0.14$ \\
Ağırlık ölçümleri $(\mathrm{g})$ & $4.61 \pm 0.33$ \\
\hline
\end{tabular}

Tablo 2. Meyve örneklerinin renk ölçüm değerleri

\begin{tabular}{cc}
\hline & Ortalama \\
\hline $\mathrm{L}^{*}$ & $15.79 \pm 094$ \\
$\mathrm{a}^{*}$ & $13.50 \pm 2.59$ \\
$\mathrm{~b}^{*}$ & $-2.32 \pm 0.78$ \\
$\Delta \mathrm{L}^{*}$ & $7.48 \pm 0.94$ \\
$\Delta \mathrm{a}^{*}$ & $17.07 \pm 2.62$ \\
$\Delta \mathrm{b}^{*}$ & $-5.11 \pm 0.78$ \\
$\Delta \mathrm{E}^{*}$ & $19.43 \pm 2.19$ \\
\hline
\end{tabular}

Sonuçlar ortalama \pm standart sapma ile gösterildi. $L^{*}$ : Rengin açıklığı, a*: Kırmızı-yeşil renk ekseni, $b^{*}$ : Sarı-mavi renk ekseni. $L^{*}, a^{*}, b^{*}:$ Mutlak değer; $\Delta L^{*}, \Delta a^{*}, \Delta b^{*}, \Delta E^{*}$ : Renk fark1.

Yapılan analizler sonucunda karadut meyve

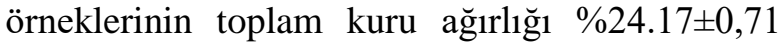
olarak hesaplanmıştır. Benzer çalışmalarla kıyaslandığında, çalışmada kullanılan karadut meyvelerinin kuru ağırlık bakımından ortalamanın üzerinde bir değere sahip olduğu söylenebilir (Güneş ve Çekiç, 2004; Ercişli ve Orhan, 2007). 
Meyvelerin $\mathrm{pH}$ değeri ise $3.66 \pm 0,8$ olarak belirlenmiştir. Y1lmaz vd., (2012)'nin Erzincan bölgesindeki karadutlar üzerine yapmış oldukları çalışmada, benzer $\mathrm{pH}$ değerleri rapor edilmiştir.

Bir meyvenin pomolojik özellikleri onun kalitesini gösteren parametrelerdendir. Elde edilen sonuçlar birlikte değerlendirildiğinde, çalışmada kullanılan karadut meyvesinin literatüre göre daha yüksek kalitede olduğu söylenebilir.

\subsection{Toplam Fenolik-Flavonoid İçerikleri}

Morus nigra L.'nın farklı ekstraktlarının toplam fenolik ve flavonoid içerik değerleri Tablo 3'te verilmiştir. Buna göre, MN1 (2.54 mg GAE/g $\mathrm{TM})$ en yüksek toplam fenolik ve flavonoid ( 0.35 mg QE/g TM) içeriğe sahipken, her iki analizde de benzer biçimde MN2 $>\mathrm{MN} 3$ sıralamas1 gözlenmiştir $(p<0.05)$. Dört farklı karadut genotipi üzerinde yapılan bir çalışmada, toplam fenolik içerik 1.83-2.49 $\mathrm{mg} / \mathrm{g} \quad$ (GAE/TM) aralığında bulunmuştur (Ercişli vd., 2010). Buna göre, çalışmada kullanılan etanolik meyve ekstraktlarının fenolik içerik bakımından oratalama bir değerle, literatüre uygun olduğu görülmüş̧ür. Ancak, flavonoid içerik bakımından literatürdeki benzer çalışmalarla kıyaslandığında, tüm ekstraktların daha düşük değere sahip olduğu ortaya çıkmıştır (Ercişli ve Orhan, 2007; Mahmoud vd., 2014). Bu durumun, kullanilan ekstraksiyon metodundan veya bitkinin yetişme koşullarından kaynaklanması muhtemeldir.

Tablo 3. Ekstraktların toplam fenolik ve flavonoid içerik analiz sonuçları

\begin{tabular}{ccc}
\hline Ekstraktlar & $\begin{array}{c}\text { Toplam Fenolik } \\
\text { Miktar1 } \\
\text { mg/g } \\
(\mathrm{GAE} / \mathrm{TM})\end{array}$ & $\begin{array}{c}\text { Toplam } \\
\text { Flavonoid } \\
\text { Miktar1 } \\
(\mathrm{QE} / \mathrm{TM})\end{array}$ \\
\hline MN1 & $2.54 \pm 0.11^{\mathrm{a}}$ & $0.35 \pm 0.002^{\mathrm{a}}$ \\
MN2 & $1.79 \pm 0.09^{\mathrm{b}}$ & $0.23 \pm 0.01^{\mathrm{b}}$ \\
MN3 & $1.54 \pm 0.04^{\mathrm{c}}$ & $0.15 \pm 0.01^{\mathrm{c}}$ \\
\hline
\end{tabular}

GAE: Gallik asit eşdeğeri, QE: Kuersetin eşdeğeri, TM: Taze meyve, MN1: $M$. nigra L. etanol ekstrakt1, MN2: M. nigra L. metanol ekstrakt1, MN3: M. nigra L. etil asetat ekstrakt1. Sonuçlar ortalama \pm standart sapma ile gösterildi ve $p<0.05$ değerleri anlamlı olarak kabul edildi. Aynı sütunda yer alan küçük harfler (a, b, c) istatistiksel olarak anlamlı farklılıkları göstermektedir.

\subsection{Antioksidan Aktivite Analizleri}

Karadut meyve örneklerinin antioksidan kapasitesinin belirlenmesi için yaygın olarak kullanilan DPPH, ABTS ve Fosfomolibdat metotları tercih edilmiştir. DPPH radikali süpürme aktivitesi sonuçları Tablo 4'te verilmiştir. Buna göre, MN2'nin $\mathrm{IC}_{50}$ (bu değerin düşük olması aktivitenin yüksek olduğunu belirtmektedir) değerinin $(143 \pm 0.2 \mu \mathrm{g} / \mathrm{ml})$ en düşük olduğu ortaya çıkmıştır $(p<0.05)$. Ayrıca, askorbik asit eşdeğeri bakımından ise MN1 (6.96 $\pm 0.36 \mathrm{mg}$ AAE/g TM), troloks eşdeğeri olarak MN2'nin (7.25 $\pm 0.49 \mathrm{mg}$ TE/g TM) en yüksek değere sahip olduğu görülmüştür $(p<0.05)$. MN3'ün radikal süpürme etkinliğinin de diğerlerine oranla en düşük olduğu tespit edilmiştir $\left(\mathrm{IC}_{50}: 722.7 \pm 0.3 \mu \mathrm{g} / \mathrm{ml}\right)(p<0.05)$. Bütün bu sonuçlar birlikte değerlendirildiğinde, antioksidan içerikleri yüksek olan ekstraktların antioksidan aktivite bakımından da yüksek olduğu gibi bir çıkarım yapılabilir. Ercişli vd., (2010) dört farklı karadut genotipi üzerinde yaptıkları çalışmada örneklerin DPPH analiz sonuçlarını 4.06-5.30 mg TE/ g TM olarak rapor etmişlerdir. Li vd., (2018)'e göre ise karadut örneklerinin antioksidan kapasiteleri benzer yöntemle $6.43 \mathrm{mg}$ AAE/ g TM olarak bulunmuştur. Jelled vd., (2017) ise ayn klimatik etmenler altında fakat farklı bölgelerde yetişen dört karadut örneğinin antioksidan kapasitelerini $\mathrm{IC}_{50}$ parametresine göre değerlendirmiştir ve DPPH radikali yakalama analizi için, 1.1-6.11 mg/ml olarak rapor etmişlerdir. $\mathrm{Bu}$ bilgiler 1şı̆̆ında, çalışmada kullanılan karadut meyvelerinin yüksek bir rakikal süpürücü etkisi olduğu söylenebilir.

Karadut meyvelerinin antioksidan kapasitelerinin belirlenmesi amaciyla yapılan ABTS radikali süpürücü aktivitesi sonuçları Tablo 3'te verilmiştir. Buna göre, sırasıyla ekstrakların aktiviteleri MN1>MN2>MN3 olarak bulunmuştur $(p<0.05)$. Diğer yandan, MN1 ve MN2'nin ABTS radikali süpürme kapasitesinin, standart olarak kullanılan troloks ve askorbik asitin kapasitesine yakın olduğu belirlenmiştir. 14 karadut çeşidi üzerine yapılan bir çalışmada ABTS radikali süpürme aktiviteksinin 1.7-3.6 mg TE/g TM olduğu rapor edilmiştir (Kafkas vd., 2008). Benzer yöntemin kullanıldığı başka bir çalışmada ise, karadut örneklerinin aktivitesi $2.51 \mathrm{mg} \mathrm{AAE} / \mathrm{g}$ TM olarak belirlenmiştir (Li vd., 2018). Jelled vd., (2017) ise aynı klimatik etmenler altında fakat farklı bölgelerde yetişen dört karadut örneğinin $\mathrm{IC}_{50}$ değerlerinin $3.0-6.5 \mathrm{mg} / \mathrm{ml}$ olduğunu rapor etmişlerdir. Sonuçlar kendi içinde de kıyaslandığında, ekstraktların DPPH aktiviteleri ile de uyumlu olduğu ve radikal süpürme aktivitesi bakımından etanol ekstraktının ön plana çıktığı görülmektedir $(p<0.05)$. Ayrıca, elde edilen sonuçlar antioksidan aktivite ile toplam biyoaktif madde içerikleri arasında bir ilişki olduğuna dikkat çekmektedir. 
Karadut meyve örneklerinin antioksidan kapasitesinin belirlenmesi amaciyla kullanılan diğer bir yöntem olan fosfomolibden analiz sonuçları Tablo 3'te verilmiştir. MN1 ve MN2 toplam antioksidan kapasite açısından daha yakın sonuçlar sergilerken, MN3'ün anlamlı bir biçimde diğerlerinden düşük olduğu tespit edilmiştir $(p<0.05)$. Literatürde, benzer yöntemin kullanıldığı kısıtlı çalışmalar bulunmaktadır.
Örneğin, bir çalışmada M. nigra L. meyvelerinin toplam antioksidan kapasitesi $1.8 \mathrm{mg}$ AAE/ g TM olarak tespit edilmiştir (Özden ve Ö̈zden, 2014). Buna göre, mevcut çalışmadan elde edilen sonuçların (MN1: 21.70, MN2: 20.83, MN3: $15.41 \mathrm{mg} \quad \mathrm{AAE} / \mathrm{g} \quad \mathrm{TM})$ literatürle karşılaştırıldığında hayli yüksek olduğu görülmüştür.

Tablo 4. Ekstraktların antioksidan özellikleri

\begin{tabular}{lccccccc}
\hline & \multicolumn{3}{c}{ DPPH } & \multicolumn{2}{c}{ ABTS } & \multicolumn{2}{c}{ TAK } \\
\hline & $\begin{array}{c}\text { mgAAE } \\
/ \mathrm{gTM}\end{array}$ & $\mathrm{mgTE} / \mathrm{gTM}$ & $\mathrm{IC}_{50}(\mu \mathrm{g} / \mathrm{ml})$ & $\begin{array}{c}\mathrm{mgAAE} \\
/ \mathrm{gTM}\end{array}$ & $\begin{array}{c}\text { mgTE } \\
/ \mathrm{gTM}\end{array}$ & $\begin{array}{c}\mathrm{IC}_{50} \\
(\mu \mathrm{g} / \mathrm{ml})\end{array}$ & $\begin{array}{c}\text { mgAAE } \\
/ \mathrm{gTM}\end{array}$ \\
\hline MN1 & $6.96 \pm 0.36^{\mathrm{a}}$ & $6.63 \pm 0.36^{\mathrm{b}}$ & $172.5 \pm 0.19^{\mathrm{b}}$ & $5.22 \pm 0.01^{\mathrm{a}}$ & $4.36 \pm 0.15^{\mathrm{a}}$ & $218.2 \pm 0.17^{\mathrm{c}}$ & $21.70 \pm 0.21^{\mathrm{a}}$ \\
MN2 & $6.47 \pm 0.22^{\mathrm{a}}$ & $7.25 \pm 0.49^{\mathrm{a}}$ & $143 \pm 0.2^{\mathrm{c}}$ & $3.93 \pm 0.07^{\mathrm{b}}$ & $3.45 \pm 0.24^{\mathrm{b}}$ & $295.1 \pm 0.4^{\mathrm{b}}$ & $20.83 \pm 0.06^{\mathrm{b}}$ \\
MN3 & $1.08 \pm 0.01^{\mathrm{b}}$ & $1.03 \pm 0.02^{\mathrm{c}}$ & $722.7 \pm 0.3^{\mathrm{a}}$ & $1.05 \pm 0.03^{\mathrm{c}}$ & $1.09 \pm 0.08^{\mathrm{c}}$ & $622.2 \pm 0.3^{\mathrm{a}}$ & $15.41 \pm 0.10^{\mathrm{c}}$ \\
AA & & & $64.2 \pm 0.16^{\mathrm{d}}$ & & & $72.8 \pm 0.18^{\mathrm{d}}$ & \\
T & & & $52.7 \pm 0.17^{\mathrm{e}}$ & & & $64.1 \pm 0.1^{\mathrm{e}}$ & \\
\hline
\end{tabular}

Sonuçlar ortalama \pm standart sapma ile gösterildi. TAK: Toplan antioksidan kapasite, A.A: Askorbik asit, T: Troloks, AAE: Askorbik asit eşdeğeri, TE: Troloks eşdeğeri, TM: Taze meyve, MN1: M. nigra L. etanol ekstrakt1, MN2: M. nigra L. metanol ekstrakt1, MN3: M. nigra L. etil asetat ekstraktı. Meyve ekstraktlarının analiz sonuçları arasındaki farklılıklar Duncan'ın çoklu karşıllaştırma testi ile analiz edildi ve $p<0.05$ değerleri anlamlı olarak kabul edildi. Aynı sütunda yer alan küçük harfler (a, b, c, d,e e $)$ istatistiksel olarak anlamlı farkl11ıkları göstermektedir.

\subsection{Fenolik Bileşik İçerik Analiz Sonuçları (HPLC)}

Total fenolik, total flavonoid ve toplam antioksidan analizleri sonucunda en yüksek içeriğe sahip olan MN1 (etanol ekstraktı)'in HPLC ile fenolik içerik analizi yapılmış ve sonuçlar Tablo 5'te belirtilmiştir. Kromotogramlar ise Şekil 1'de gösterilmiştir. Sonuçlara göre, etanol ekstraktında 23 fenolik bileşik taranmış ve bunlardan 11 tanesinin bulunduğu görülmüştür. Bununla birlikte, ekstraktta en fazla bulunan bileşenin klorojenik asit (405.9 $\mu \mathrm{g} / \mathrm{g}$ ekstrakt) olduğu ve bunu rutin (313.3 $\mu \mathrm{g} / \mathrm{g}$ ekstrakt), protokatekuik asit $(133.0 \mu \mathrm{g} / \mathrm{g}$ ekstrakt), apigenin (112.4 $\mu \mathrm{g} / \mathrm{g}$ ekstrakt), kuersetin (108.5 $\mu \mathrm{g} / \mathrm{g}$ ekstrakt), sinnamik asit $(57.0 \mu \mathrm{g} / \mathrm{g}$ ekstrakt), kaemferol (47.9 $\mu \mathrm{g} / \mathrm{g}$ ekstrakt), $p$-hidroksi benzoik asit $(43.0 \mu \mathrm{g} / \mathrm{g}$ ekstrakt), gallik asit $(37.4 \mu \mathrm{g} / \mathrm{g}$ ekstrakt), kafeik asit (17.4 $\mu \mathrm{g} / \mathrm{g}$ ekstrakt) ve $p$ kumarik asit $(14.7 \mu \mathrm{g} / \mathrm{g}$ ekstrakt)'in takip ettiği görülmüştür. Bunlardan özellikle, klorojenik asit'in bitkilerde antioksidan ve antimikrobiyal aktiviteler başta olmak üzere, pek çok biyolojik aktiviteden sorumlu olduğu bilinmektedir (Özcan, 2019; Acet, 2020). Yine, klorojenik asit'in dut meyvelerinde bulunan başlica fenolik bileşenlerden biri olduğu ve bu durumun bitkinin geniş çaplı teropatik kullanımları ile ilişkili olduğu rapor edilmiştir (Dhiman vd., 2020). Gundogdu vd., (2011)'nin kara dut üzerine yapmış olduğu bir çalışmada, klorojenik asit'in $3.106 \mathrm{mg} / \mathrm{g}$ TM olduğu bulunmuştur. Bu sonucun mevcut çalışmaya göre yüksek olduğu görülmektedir ancak bu farklılığın ekstraksiyon metodundaki farklılıktan kaynaklanabileceği düşünülmektedir. Bununla birlikte, $M$. nigra meyve ekstraktlarının HPLC ile fenolik içeriğinin aydınlatıldığ 1 başka bir çalışmada klorojenik asit'in $358 \mu \mathrm{g} / \mathrm{g} \quad \mathrm{TA}$ olduğu bulunmuştur (Pehluvan vd., 2015). Bununla birlikte, Turan vd., (2017) karadut üzerine yapmış oldukları çalışmalarında, klorojenik asit miktarını 309.6 $\mu \mathrm{g} / \mathrm{g}$ ekstrakt olarak tespit etmişleridir. Bununla kıyaslandığında, mevcut çalışmadaki meyve ekstaktının fenolik miktarının (405.9 $\mu \mathrm{g} / \mathrm{g}$ ekstrakt), daha yüksek olduğu ve elde edilen sonuçların literatürle kıyaslanabilir olduğu ortaya çıkmaktadır. Bununla birlikte, ekstrede tespit edilen diğer bileşenlerin pek çok biyolojik aktiviteden sorumlu oldukları daha önceki çalışmalarla ortaya konmuştur (Özcan vd., 2019; Dhiman vd., 2020). Dolayısıyla, ekstrakttaki majör ve minör fenolik bileșenlerin mevcut antioksidan ve antimikrobiyal etkinliklerden sorumlu olabileceği düşünülmektedir. 
Tablo 5. Etanol ekstraktının fenolik bileşen analizi

\begin{tabular}{ccc}
\hline No & Fenolik bileşen & Miktar $(\mu \mathrm{g} / \mathrm{g}$ ekstrakt $)$ \\
\hline 1 & Gallik asit & $37.4 \pm 0.31$ \\
2 & Protokatekuik asit & $133.0 \pm 0.80$ \\
3 & Kateşin & $*$ \\
4 & $p$-hidroksi benzoik asit & $43.0 \pm 0.25$ \\
5 & Klorojenik asit & $405.9 \pm 0.61$ \\
6 & Kafeik asit & $17.4 \pm 0.25$ \\
7 & Epikateşin & $*$ \\
8 & Şiringik asit & $*$ \\
9 & Vanilin & $*$ \\
10 & $p$-kumarik asit & $14.7 \pm 0.15$ \\
11 & Ferulik asit & $*$ \\
12 & Sinapinik asit & $*$ \\
13 & Benzoik asit & $*$ \\
14 & $o$-kumarik asit & $*$ \\
15 & Rutin & $313.3 \pm 0.35$ \\
16 & Hesperidin & $*$ \\
17 & Rosmarinik asit & $*$ \\
18 & Eriodiktiol & $*$ \\
19 & Sinnamik asit & $57.0 \pm 0.15$ \\
20 & Kuersetin & $108.5 \pm 0.26$ \\
21 & Luteolin & $*$ \\
22 & Kaemferol & $47.9 \pm 0.21$ \\
23 & Apigenin & $112.4 \pm 0.32$ \\
& & \\
\hline & &
\end{tabular}

Sonuçların üç paralel üzerinde ortalaması alındı ve ortalama \pm standart sapma olarak verildi. *Tespit edilemedi.

\subsection{Dut Ekstraktlarının Antimikrobiyal Özelliklerinin ve Antibiyotiklerle Olan Sinerjisinin Belirlenmesi}

Ekstraktların antimikrobiyal aktivitesi disk difüzyon ve mikrodilüsyon yöntemleriyle belirlenmiştir. Ekstraktlara ait disk difüzyon inhibisyon ölçümleri Tablo 6, mikrodilüsyon testi sonucu belirlenen MIKK değerleri Tablo 7 ve MBK değerleri Tablo 8'de verilmiştir. Standart antibiyotik olarak novobiosin, kloramfenikol ve nalidiksik asit kullanılmıştır. Ekstraktların kullanılan antibiyotikler ile seçilen önemli dirençli patojen organizmalar (Enterococcus faecium DSMZ 13590, MRSA ATCC 43300 ve Pseudomonas aeruginosa ATCC 27853) üzerine Checkboard yöntemi ile belirlenen sinerjistik etkisinin ifade edilmesinde kullanılan FICI değerleri Tablo 9'da verilmiştir.
Karadut ile yapılan çalışmalarda Dimitrova vd., (2014) agar difüzyon yöntemi ile karadut meyvelerinin antimikrobiyal etkinliklerini Listeria monocytogenes, Staphylococcus aureus, Escherichia coli'ye karşı test ettiklerini ve sirasiyla 12, 6, 11 mm'lik zon çapları belirlediklerini rapor etmişlerdir. Çalışmamızda da kullanılan ekstraktların Staphylococcus aureus'a karşı göstermiş olduğu antimikrobiyal etkinin dikkate değer olduğu görülmektedir. Başka bir çalışmada ise Yiğit ve Yiğit (2008), karadut meyvelerinin metanolik ekstraklarının antimikrobiyal etkisini; Staphylococcus aureus ve Escherichia coli için $10 \mathrm{~mm}$ zon çap1 olarak belirlemişlerdir. Pseudomonas aeroginosa'ya karş1 ise antimikrobiyal bir aktivite belirlemediklerini rapor etmişlerdir. 
a-)

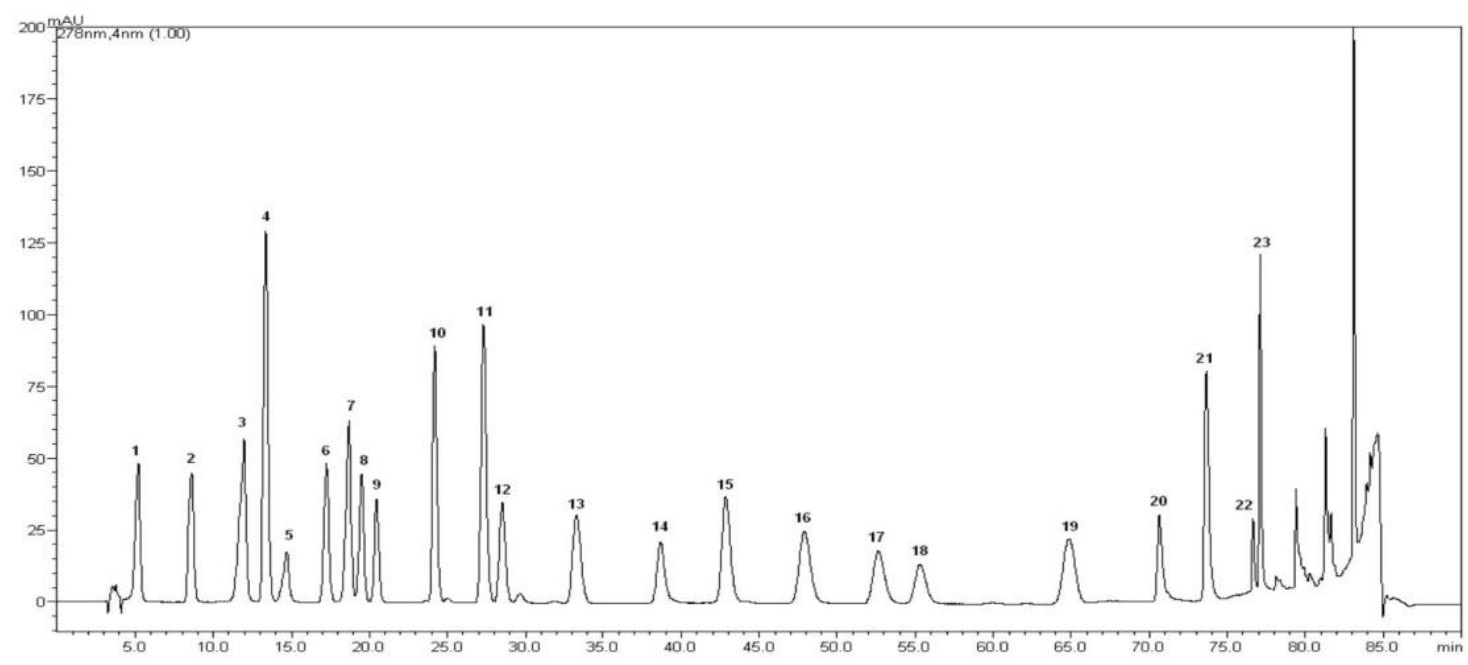

b-)

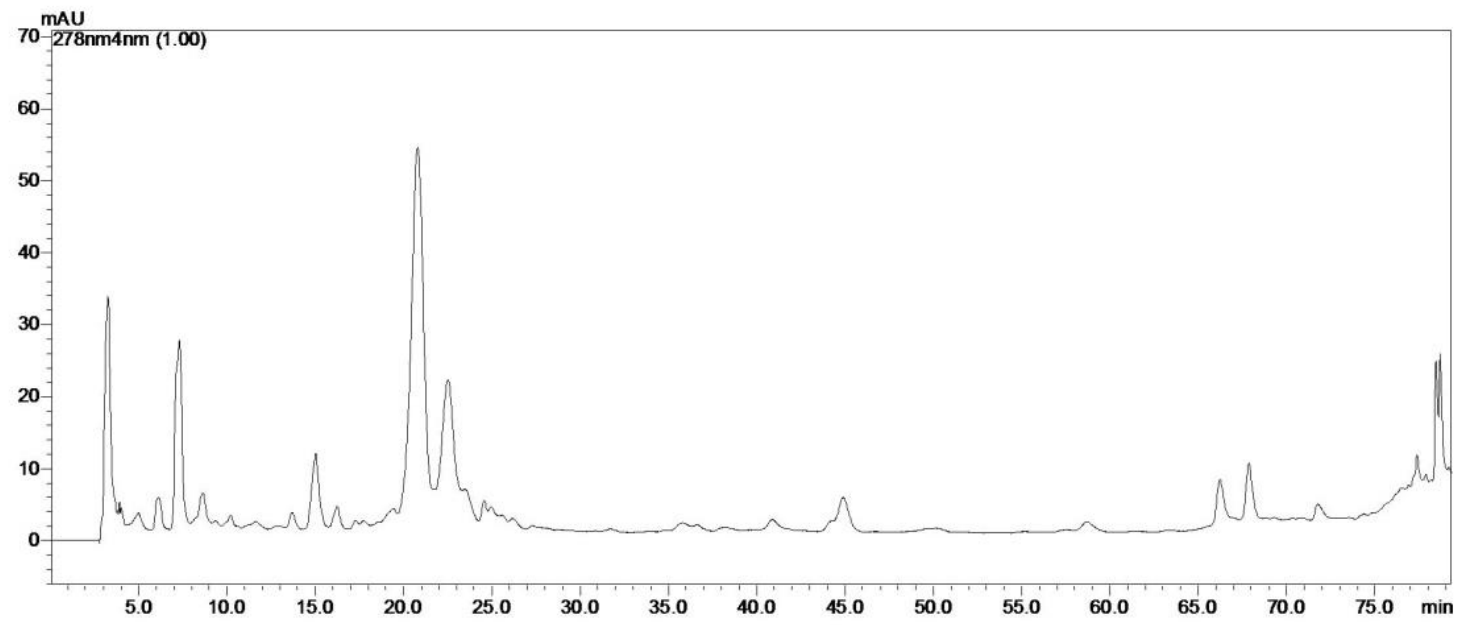

Şekil 1. Morus nigra'nın fenolik bileşenlerine ait RP-HPLC kromotogramları, a-) Standartlar (*), b-) bitkinin etanol ekstakt1

(*) 1: gallic acid, 2: protocatechic acid, 3: catechin, 4: p-hydroxy benzoic acid, 5: chlorogenic acid, 6: caffeic acid, 7: epicatechin, 8: syringic acid, 9: vanilin, 10: p-coum acid, 11: ferulic acid, 12: sinapinic acid, 13: benzoic acid, 14: $o$-coum acid, 15: rutin, 16: hesperidin, 17: rosmarinic acid, 18: eriodictiol, 19: cinnamic acid, 20: quercetin, 21: luteolin, 22: kamferol, 23: apigenin

Çalışmamızda Pseudomonas aeroginosa'ya karşı antibakteriyel aktivite tespit edilmiştir. Ekstraktların patojen mikroorganizmalar üzerine etkinlik konsantrasyonunu belirleyen MiK değerlerine bakıldığında düşük etkinlik gösterdikleri anlaşılmaktadır. MN3 ekstraktının $E$. faecalis: $256 \mu \mathrm{g} / \mathrm{ml}$ ve L. monocytogenes: 512 $\mu \mathrm{g} / \mathrm{ml}$ MIK değerleri diğer ekstraktlara nazaran daha etkili bulunmuştur. Yiğit ve Yiğit (2008), karadut meyvelerinin metanolik ekstraktlarının Staphylococcus aureus ve Escherichia coli'ye karş1 $0.625 \mathrm{mg} / \mathrm{ml}$ 'lik MİK değeri gösterdiğini rapor etmişlerdir.

Yapılan literatür taraması sonucunda Morus nigra L. meyvelerinin antibiyotiklerle sinerjistik etkisini irdeleyen çalışma tespit edilememiştir. Fakat farklı bitki ekstraktlarının antibiyotiklerle sinerjistik etkileşimlerde bulundukları üzerine çalışmalar mevcuttur (Özcan ve Acet, 2018; Vambe vd., 2018; Kuok vd., 2017). Dut ekstraktlar1/novobiosin denemelerinde test edilen mikroorganizmalara karş1 MN3/novobiosin haricinde tam sinerji görülmüştür. Dut ekstraktları /kloramfenikol MN3/kloramfenikol tüm organizmalar, MN1/kloramfenikol ise $P$. aeruginosa üzerine tam sinerji gösterirken, dut ekstraktları/nalidiksik asit uygulamalarında tüm ekstraktlar sadece $P$. aeruginosa'ya tam sinerji sergilerken diğer ekstrakt ve antibiyotik kombinasyonları herhangi bir sinerjistik etkileşim göstermemiştir. Tüm sonuçlar beraber değerlendirildiğinde ekstrakt ve antibiyotiklerin birlikte uygulamaları $P$. aeruginosa üzerine oldukça etkili bulunmuştur. Ekstraktların antibiyotiklerle sinerjik aktivite göstermeleri daha düşük antibiyotik uygulamaları ile ilgili patojenlerle mücadele edilebileceğini göstermektedir. $\mathrm{Bu}$ durumda normalde antimikrobiyal etkinliği düşük olan dut ekstraktlarının kullanılan antibiyotiklerin etkinliğini arttırdığı açıkça görülmektedir. 
Tablo 6. Ekstraktların patojen mikroorganizmalara karşı inhibisyon zon ölçümleri (mm)

\begin{tabular}{|c|c|c|c|c|c|c|}
\hline Ekstraktlar & MN1 & MN2 & MN3 & Nov. & Klor. & Nal. \\
\hline \multicolumn{7}{|c|}{ Gram (+) bakteriler } \\
\hline E. faecalis & $10.84 \pm 0.09$ & $10.24 \pm 0.12$ & $9.59 \pm 0.04$ & $14.66 \pm 0.22$ & $14.88 \pm 0.12$ & $14.21 \pm 0.17$ \\
\hline S. aureus & $11.10 \pm 0.15$ & $11.33 \pm 0.12$ & $10.30 \pm 0.06$ & $15.09 \pm 0.18$ & $15.41 \pm 0.17$ & $15.05 \pm 0.24$ \\
\hline E. faecium & $10.26 \pm 0.05$ & $10.19 \pm 0.13$ & $10.24 \pm 0.03$ & $14.39 \pm 0.15$ & $15.01 \pm 0.10$ & $14.56 \pm 0.46$ \\
\hline B. cereus & $9.50 \pm 0.15$ & $9.50 \pm 0.11$ & $9.90 \pm 0.05$ & $14.73 \pm 0.15$ & $14.74 \pm 0.17$ & $14.54 \pm 0.18$ \\
\hline L.monocytogenes & $9.55 \pm 0.10$ & $9.12 \pm 0.07$ & $8.90 \pm 0.04$ & $15.05 \pm 0.19$ & $14.52 \pm 0.28$ & $14.44 \pm 0.21$ \\
\hline MRSA & $8.91 \pm 0.14$ & $8.82 \pm 0.07$ & $8.59 \pm 0.03$ & $13.23 \pm 0.22$ & $13.15 \pm 0.18$ & $13.23 \pm 0.22$ \\
\hline \multicolumn{7}{|c|}{ Gram (-) bakteriler } \\
\hline P. aeruginosa & $10.21 \pm 0.11$ & $10.09 \pm 0.09$ & $11.39 \pm 0.08$ & $14.43 \pm 0.11$ & $14.50 \pm 0.15$ & $14.47 \pm 0.16$ \\
\hline Y.enterocolitica & $8.86 \pm 0.11$ & $8.42 \pm 0.06$ & $8.17 \pm 0.17$ & $13.80 \pm 0.22$ & $14.10 \pm 0.23$ & $13.47 \pm 0.20$ \\
\hline K. pneumoniae & $9.20 \pm 0.06$ & $9.02 \pm 0.06$ & $8.82 \pm 0.05$ & $14.80 \pm 0.13$ & $14.74 \pm 0.10$ & $14.45 \pm 0.12$ \\
\hline V.parahaemolyticus & $9.83 \pm 0.11$ & $10.73 \pm 0.05$ & $10.25 \pm 0.10$ & $14.47 \pm 0.17$ & $14.84 \pm 0.12$ & $14.27 \pm 0.17$ \\
\hline E.coli $\mathrm{O} 157: \mathrm{H} 7$ & $10.36 \pm 0.13$ & $9.30 \pm 0.06$ & $9.04 \pm 0.07$ & $14.87 \pm 0.10$ & $14.71 \pm 0.15$ & $14.19 \pm 0.23$ \\
\hline P. vulgaris & $10.11 \pm 0.14$ & $9.87 \pm 0.10$ & $9.55 \pm 0.09$ & $14.83 \pm 0.18$ & $14.94 \pm 0.19$ & $14.18 \pm 0.16$ \\
\hline \multicolumn{7}{|c|}{ Maya ve Küf } \\
\hline C. tropicalis & $11.97 \pm 0.12$ & $9.79 \pm 0.03$ & $9.91 \pm 0.04$ & - & - & - \\
\hline A. flavus & $10.58 \pm 0.13$ & $9.25 \pm 0.06$ & $9.05 \pm 0.10$ & - & - & - \\
\hline
\end{tabular}

MN1: . nigra L. etanol ekstrakt1, MN2: M. nigra L. metanol ekstrakt1, MN3: M. nigra L. etil asetat ekstrakt1, Nov.: Novobiosin, Klor.: Kloramfenikol, Nal.: Nalidiksik asit.

Tablo 7. Ekstraktlar ve antibiyotiklerin mikroorganizmalara karşı MíK değerleri (mg/ml)

\begin{tabular}{|c|c|c|c|c|c|c|}
\hline Ekstraktlar & MN1 & MN2 & MN3 & Nov. & Klor. & Nal. \\
\hline \multicolumn{7}{|c|}{ Gram (+) bakteriler } \\
\hline E. faecalis & 4.1 & 2.05 & 0.256 & 0.016 & 0.016 & 0.016 \\
\hline S. aureus & 8.2 & 8.2 & 8.2 & 0.128 & 0.128 & 0064 \\
\hline E. faecium & 4.1 & 2.05 & 1.025 & 0.001 & 0.004 & 0.064 \\
\hline B. cereus & 8.2 & 8.2 & 8.2 & 0.016 & 0.016 & 0.032 \\
\hline L.monocytogenes & 8.2 & 8.2 & 0.512 & 0.016 & 0.016 & 0.032 \\
\hline MRSA & 1.25 & 2.05 & 4.1 & 0.001 & 0.032 & 0.032 \\
\hline \multicolumn{7}{|c|}{ Gram (-) bakteriler } \\
\hline P. aeruginosa & 4.1 & 4.1 & 4.1 & 0.001 & 0.004 & 0.032 \\
\hline Y.enterocolitica & 4.1 & 4.1 & 4.1 & 0.032 & 0.032 & 0.064 \\
\hline K. pneumoniae & 4.1 & 4.1 & 4.1 & 0.032 & 0.032 & 0.128 \\
\hline V.parahaemolyticus & 8.2 & 8.2 & 8.2 & 0.128 & 0.064 & 0.128 \\
\hline E.coli $\mathrm{O} 157: \mathrm{H} 7$ & 8.2 & 8.2 & 8.2 & 0.064 & 0.016 & 0.064 \\
\hline P. vulgaris & 2.05 & 2.05 & 2.05 & 0.064 & 0.032 & 0.032 \\
\hline \multicolumn{7}{|c|}{ Maya ve Küf } \\
\hline C. tropicalis & 8.2 & 8.2 & 8.2 & 0.008 & 0.016 & 0.032 \\
\hline A. flavus & 8.2 & 8.2 & 8.2 & 0.008 & 0.016 & 0.064 \\
\hline
\end{tabular}

MN1: Morus nigra L. etanol ekstrakt1, MN2: Morus nigra L. metanol ekstrakt1, MN3: Morus nigra L. etil asetat ekstrakt1.

Tablo 8. Ekstraktların patojen mikroorganizmlara karşı MBK değerleri $(\mathrm{mg} / \mathrm{ml})$

\begin{tabular}{cccc}
\hline Ekstraktlar & MN1 & MN2 & MN3 \\
\hline Gram (+) bakteriler & & & 0.512 \\
E. faecalis & 4.1 & 4.1 & 8.2 \\
S. aureus & 8.2 & 8.2 & 2.05 \\
E. faecium & 4.1 & 4.1 & 8.2 \\
B. cereus & 8.2 & 8.2 & 1.025 \\
L.monocytogenes & 8.2 & 8.2 & 4.1 \\
MRSA & 2.05 & 4.1 & 4.1 \\
Gram (-) bakteriler & 4.1 & 4.1 & 4.1 \\
P. aeruginosa & 4.1 & 4.1 & 4.1 \\
Y.enterocolitica & 4.1 & 4.1 & 8.2 \\
K. pneumoniae & 8.2 & 8.2 & 8.2 \\
V.parahaemolyticus & 8.2 & 8.2 & 4.1 \\
E.coli O157:H7 & 4.1 & 4.1 & 8.2 \\
P. vulgaris & & & 8.2 \\
\hline Maya ve Küf & 8.2 & 8.2 & 8.2 \\
A. flapicalis & 8.2 & & . \\
\hline
\end{tabular}

MN1: M. nigra L. etanol ekstrakt1, MN2: . nigra L. metanol ekstrakt1, MN3: M. nigra L.etil asetat ekstrakt1, TM: Taze meyve. 
Tablo 9. Ekstrakt ve antibiyotik karışımlarının FICI değerleri

\begin{tabular}{cccc}
\hline Ekstrakt+antibiyotik & P. aeruginosa & MRSA & E. faecium \\
\hline MN1/Nov. & 0.25 & 0.25 & 0.5 \\
MN2/Nov. & 0.25 & 0.25 & 0.25 \\
MN3/Nov. & 0.06 & 0.12 & 1 \\
MN1/Klor. & 0.5 & 1 & 1 \\
MN2/Klor. & 1 & 1 & 2 \\
MN3/Klor. & 0.06 & 0.06 & 0.12 \\
MN1/Nal. & 0.5 & 2 & 1 \\
MN2/Nal. & 0.5 & 2 & 2 \\
MN3/Nal. & 0.03 & 1 & 2 \\
\hline
\end{tabular}

MN1/Nov.: M. nigra L. etanol ekstrakt1 + novobiosin, MN1/Klor.: M. nigra L. etanol ekstrakt1 + kloramfenikol, MN1/Nal.: M. nigra L. etanol ekstrakt1 + nalidiksik asit, MN2/Nov.: M. nigra L. metanol ekstrakt1 + novobiosin, MN2/Klor.: $M$. nigra L. metanol ekstrakt1 + kloramfenikol, MN2/Nal.: M. nigra L. metanol ekstrakt1 + nalidiksik asit, MN3/Nov.: M. nigra L.etil asetat ekstrakt1 + novobiosin, MN3/Klor.: M. nigra L.etil asetat ekstrakt1 + kloramfenikol, MN3/Nal.: M. nigra L.etil asetat ekstrakt1 + nalidiksik asit. $\mathrm{FICI} \leq 0.5$ tam sinerji, $0.5<\mathrm{FICI} \leq 0.75 \mathrm{k} 1 \mathrm{smi}$ sinerji, $0.76<\mathrm{FICI} \leq 1)$ sinerjistik etkileşimin olmaması ve FICI $>2$ antagonistik etkilişim olarak değerlendirildi.

\section{Sonuçlar}

Sonuç olarak, bu çalışmada Elazı̆ğdan toplanan Morus nigra meyvelerine ait ekstraktların sinerjistik aktivitesi ilk defa rapor edilmiştir. Bu bağlamda, çalışılan ekstraktların antibiyotiklerle beraber kullanıldı̆̆ında antibiyotiğin antimikrobiyal etkinliğini arttırdığ tespit edilmiştir. Böylece antibiyotiklerin daha düşük dozlarda kullanılmaları ile antibiyotik dirençlilik konsantrasyonlarının düşük tutulması mümkün olabilecektir. Ayrıca klorojenik asit, etanol ekstraktının ana bileşeni olarak tespit edilmiştir. Ekstraktların antioksidan ve antimikrobiyal etkilerinin içerdikleri majör ve minör bileşenlerin birlikte oluşturduğu etkiden kaynaklandığı düşünülmektedir. Dut ekstraktlarının doğal antioksidan ve antibiyotiklerle beraber kullanma potansiyeli farmasötik açıdan kullanılabilirliği olduğunu işaret etmektedir.

\section{Katkı Belirtme}

$\mathrm{Bu}$ çalışma Osman Akmeşe'nin “Morus nigra L. (Karadut) Meyve Ekstraktlarının Antimikrobiyal Aktivitesinin ve Antibiyotiklerle Sinerjistik Etkisinin Belirlenmesi” adlı yüksek lisans tezinden türetilmiştir. Çalışmalar Gümüşhane Üniversitesi ve Giresun Üniversitesi, Genetik ve Biyomühendislik araştırma laboratuvarlarında yürütülmüştür.

\section{Kaynaklar}

Acet, T., 2020. Determining the Phenolic Components by Using HPLC and Biological Activity of Centaurea triumfetti. Plant Biosystems-An International Journal Dealing with All Aspects of Plant Biology, doi: 10.1080/11263504.2020.1722275.
Alhaithloul, H.A., Soliman, M.H., Ameta, K.L., ElEsawi, M.A. ve Elkelish, A., 2020. Changes in Ecophysiology, Osmolytes, and Secondary Metabolites of the Medicinal Plants of Mentha piperita and Catharanthus roseus Subjected to Drought and Heat Stress. Biomolecules, 10, 43.

Beara, I.N., Lesjak, M.M., Cetojevic-Simin, D.D., Marjanovic, Z.S., Ristic, J.D., Mrkonjic, Z.O. ve Mimica-Dukic, N.M., 2014. Phenolic Profile, Antioxidant, Anti-Inflammatory and Cytotoxic Activities of Black (Tuber Aestivum Vittad.) and White (Tuber Magnatum Pico) Truffles. Food Chemistry, 165, 460-466.

Budiman, A., Sofian, F.F., Santi, N.M. ve Aulifa, D.L. 2020. The Formulation of Lozenge Using Black Mulberries (Morus Nigra L.) Leaf Extract as An A-Glucosidase Inhibitor. Journal of Pharmacy and Bioallied Sciences, 12, 171-176.

CLSI (Clinical and Laboratory Standards), 2007. Performance Standards for Antimicrobial Susceptibility Testing, $17^{\text {th }}$ Informational Supplement, M100-S17, 27, 1.

Diab, K.A., Fahmy, M.A., Hassan, E.M., Hassan, Z.M., Omara, E.A. ve Abdel-Samie, N.S., 2020. Inhibitory Activity of Black Mulberry (Morus Nigra) Extract Against Testicular, Liver and Kidney Toxicity Induced by Paracetamol in Mice. Molecular Biology Reports, 47, 17331749. doi.org/10.1007/s11033-020-05265-1.

Dimitrova, M.P., Mihaylova, D.S., Popova, A.T., Sapundzhieva, T.N., Alexieva, I.N. ve Fidan, H.N., 2014. Phenolic Content, Antioxidant and Antimicrobial Activity of Mulberry Fruit, International Scientific-Practical Conference Food, Technologies and Health, 2014, s. 23-27.

Dhiman, S., Kumar, V., Mehta, C.M., Gat, Y. ve Kaur, S., 2020. Bioactive Compounds, Health Benefits and Utilisation of Morus Spp.-A 
Comprehensive Review. The Journal of Horticultural Science and Biotechnology, 95(1), 8-18. doi: 10.1080/14620316.2019.1644969.

Ercisli, S. ve Orhan, E., 2007. Chemical Composition of White (Morus alba), Red (Morus rubra) and Black (Morus nigra) Mulberry fruits. Food Chemistry, 103, 1380-1384.

Ercisli, S., Tosun, M., Duralija, B., Voca, S., Sengul, M. ve Turan, M., 2010. Phytochemical Content of Some Black (Morus nigra L.) and Purple (Morus rubra L.) Mulberry Genotypes. Food Technology and Biotechnology, 48(1), 102-106.

Fadli, M., Chevalier, J., Saad, A., Mezrioui, N.E., Hassani, L. ve Pages, J.M., 2012. Antibacterial Activity of Thymus maroccanus and Thymus broussonetii Essential Oils Against Nosocomial Infection-Bacteria and Their Synergistic Potential with Antibiotics. Phytomedicine, 19, 464-471.

Gundogdu, M., Muradoglu, F., Gazioglu Sensoy, R.I. ve Yilmaz, H., 2011. Determination of Fruit Chemical Properties of Morus nigra L., Morus alba L. and Morus rubra L. by HPLC. Scientia Horticulturae, 132, 37-41.

Gunes, M. ve Cekic, C., 2004. Some Chemical and Physical Properties of Fruits of Different Mulberry Species Commonly Grown in Anatolia, Turkey. Asian Journal of Chemisrty, $16,1849-1855$.

Hojjatpanah, G., Fazaeli, M. ve Emam-Djomeh, Z., 2011. Effects of Heating Method and Conditions on the Quality Attributes of Black Mulberry (Morus nigra) Juice Concentrate. International Journal of Food Science and Technology, 46(5), 956-962.

Jelled, A., Ben Hassine, R., Thouri, A., Flamini, G., Chahdoura, H., El Arem, A., Ben Lamine, J., Kacem, A., Haouas, Z., Ben Cheikh, H. ve Achour, L., 2017. Immature Mulberry Fruits Richness of Promising Constituents in Contrast with Mature Ones: A Comparative Study Among Three Tunisian Species. Industrial Crops and Products, 95, 434-443.

Jiang, H., Xu, L., Liu, J.C. ve Huang X.Z., 2011. Research Progress on Active Ingredients and Pharmacological Functions of Black Mulberry (Morus nigra L.). Science of Sericulture, 1, 20.

Kafkas, S., Özgen, M., Doğan, Y., Özcan, B., Ercişli, S. ve Serçe, S., 2008. Molecular Characterization of Mulberry Accessions in Turkey by AFLP Markers. Journal of American Society for Horticultural Science, 133593-597.

Kostic, D.A., Dimitrijevic, D.S., Mitic, S.S., Mitic, M.N., Stojanovic, G.S. ve Zivanovic, A.V.,
2013. A Survey on Macro- and Micro-Elements, Phenolic Compounds, Biological Activity and Use of Morus Spp. (Moraceae). Fruits, 68(4), 333-47.

Kuok, C.F., Hoi, S.O., Hoi, C.F., Chan, C.H., Fong, I.H., Ngok, C.K. ve Fong, P., 2017. Synergistic Antibacterial Effects of Herbal Extracts and Antibiotics on Methicillin-resistant Staphylococcus aureus: A Computational and Experimental Study. Experimental Biology and Medicine, 242(7), 731-743.

Li, Y., Bao, T. ve Chen, W., 2018. Comparison of the Protective Effect of Black and White Mulberry Against Ethyl Carbamate-induced Cytotoxicity and Oxidative Damage. Food Chemistry, 243, 65-73.

Mahmoud, H.I., El Rab, S.M.G., Khalil, A.F. ve Ismael, S.M., 2014. Hypoglycemic Effect of White (Morus alba L.) and Black (Morus nigra L.) Mulberry Fruits in Diabetic Rat. European Journal of Chemistry, 5(1), 65-72.

Özcan, K., Acet, T. ve Çorbacı, C., 2019. Centaurea hypoleuca DC: Phenolic Content, Antimicrobial, Antioxidant and Enzyme Inhibitory Activities. South African Journal of Botany, 127, 313-318.

Özcan, K. ve Acet, T., 2018. Antimicrobial and Antioxidant Screening, Synergy Studies of Helichrysum chionophilum Extracts Against to Resistant Microbial Strains. Fresenius Environmental Bulletin, 27, 5045-5052.

Özden, M. ve Özden, A.N., 2014. Farklı Renkteki Meyvelerin Toplam Antosiyanin, Toplam Fenolik Kapsamlariyla Toplam Antioksidan Kapasitelerinin Karşılaştırılması, Gıda Teknolojileri Elektronik Dergisi, 9(2), 1-12.

Pehluvan, M., Kaya, T., Doğru, B., Lara, İ., 2015. The Effect of Frozen Storage on the Phenolic Compounds of Morus nigra L. (Mlack Mulberry) and Morus alba L. (White Mulberry) Fruit. Fruits, 70(2), 117-122.doi: doi.org/10.1051/fruits/2015004.

Rehman, K., Kamran, S.H. ve Akash, M.S.H., 2020. Chapter 16-Toxicity of Antibiotics, In Advances in Environmental Pollution Research Series, Antibiotics and Antimicrobial Resistance Genes in the Environment, Elsevier, ISBN 9780128188828, 1, 234-252p. doi: doi.org/10.1016/B978-0-12-818882-8.00016-4.

Sánchez-Salcedo, E.M., Mena, P., García-Viguera, C., Hernández, F. ve Martínez J.J. 2015. (Poly)phenolic Compounds and Antioxidant Activity of White (Morus alba) and Black (Morus nigra) Mulberry Leaves: Their Potential 
for New Products Rich in Phytochemicals. Journal of Functional Foods, 18, 1039-1047.

Silva, E.M., Souza, J.N.S., Rogez, H., Reesb, J.F. ve Larondellea, Y., 2007. Antioxidant Activities and Polyphenolic Contents of Fifteen Selected Plant Species from the Amazonian Region. Food Chemistry, 101(3), 1012-1018.

Soler-Rivas, C., Espín, J.C. ve Wichers, H.J., 2000. An Easy and Fast Test to Compare Total Free Radical Scavenger Capacity of Foodstuffs. Phytochemical Analysis, 11, 330-338.

Thakur, N., Bashir, S. F. Ve Kumar, G., 2020. Assessment of Phytochemical Composition, Antioxidant and Anti-Inflammatory Activities of Methanolic Extracts of Morus nigra and Artocarpus heterophyllus Leaves. Plant Cell Biotechnology and Molecular Biology, 21(3-4), 83-91.

Turan, İ., Demir, S., Kilinc, K., Arslan Burnaz, N., Ozer Yaman, S., Akbulut, A., Mentese, A., Aliyazicioglu, Y. ve Deger, O., 2017. Antiproliferative and Apoptotic Effect of Morus nigra Extract on Human Prostate Cancer Cells. Saudi Pharmaceutical Journal, 25 (2), 241-248.

Vambe, M., Aremu, A.O., Chukwujekwu, J.C., Finnie, J.F. ve Staden, J.V., 2018. Antibacterial Screening, Synergy Studies and Phenolic Content of Seven South African Medicinal Plants Against Drug-sensitive and -resistant Microbial Strains. South Africican Journal of Botany, 114, 250-259.

Vijayan, K., Tikader, A., Weiguo, Z., Nair, C.V., Ercisli, S. ve Tsou, C.H., 2011. Morus, in: Kole C (ed) Wild Crop Relatives: Genomic and Breeding Resources: Tropical and Subtropical Fruits. Springer, Berlin, Heidelberg, pp.75-95.

Wang, Y., Liang, Y. ve Cock, I.E., 2020. Rosa canina L. Fruit Extracts Inhibit the Growth of Bacterial Triggers of some Autoimmune Inflammatory Diseases and Potentiate the activity of Conventional Antibiotics. Pharmacognosy Communications, 10(1), 7-17.

Yan, J., Ruan, J., Huang, P., Sun, F., Zheng, D., Zhang, Y. ve Wang, T., 2020. The Structure-Activity Relationship Review of the Main Bioactive Constituents of Morus Genus Plants. Journal of Natural Medicine, 74, 331-340. Doi: doi.org/10.1007/s11418-019-01383-8.

Yiğit, D. ve Yiğit, N., 2008. Antibacterial Activty of Black Mulberry (Morus nigra) Fruits and Leaves. Erzincan Üniversitesi Fen Bilimleri Enstitüsü Dergisi, 1(1), 39-47.

Yilmaz, K.U., Zengin, Y., Ercisli, S., Demirtas, M.N., Kan, T. ve Nazli, A.R., 2012. Morphological
Diversity on Fruit Characteristics Among Some Selected Mulberry Genotypes from Turkey. The Journal of Animal and Plant Sciences, 22(1), 211-214.

Zengin, G., Sarikurkcu, C., Aktumsek, A. ve Ceylan, R., 2014. Sideritis galatica Bornm.: A Source of Multifunctional Agents for the Management of Oxidative Damage, Alzheimer's's and Diabetes Mellitus. Journal of Functional Foods, 11, 538547. 